University of Michigan Law School

University of Michigan Law School Scholarship Repository

\title{
Sales: Liability for the Presence of Mice and Other Uncommon Things in Food
}

John B. Waite

University of Michigan Law School

Available at: https://repository.law.umich.edu/articles/884

Follow this and additional works at: https://repository.law.umich.edu/articles

Part of the Commercial Law Commons, Food and Drug Law Commons, and the Torts Commons

\section{Recommended Citation}

Waite, John B. "Sales: Liability for the Presence of Mice and Other Uncommon Things in Food." Mich. L. Rev. 17, no. 3 (1919): 261-4.

This Response or Comment is brought to you for free and open access by the Faculty Scholarship at University of Michigan Law School Scholarship Repository. It has been accepted for inclusion in Articles by an authorized administrator of University of Michigan Law School Scholarship Repository. For more information, please contact mlaw.repository@umich.edu. 


\title{
Michigan LAW RevieW
}

\author{
PUBLISIED MONTHLY DURING THE ACADEMIC YEAR, EXCLUSIVE OF OCTOBER, BY THR \\ LAW SCHOOL OF THE UNIVERSITY OF MICHIGAN
}

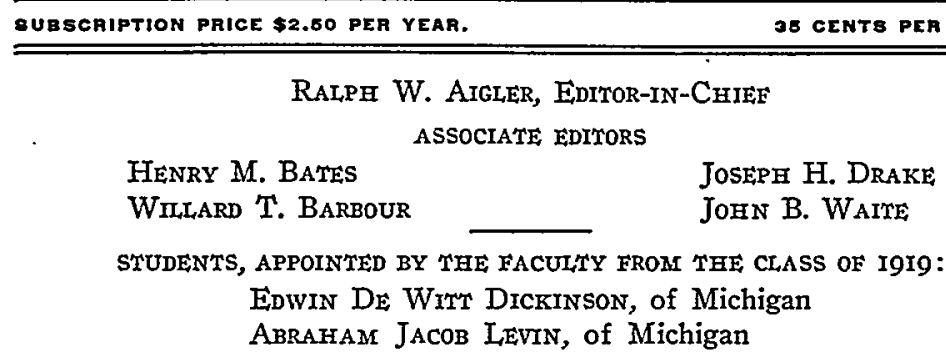

\section{NOTE AND COMMENT}

Sales-Itabitity for the Presence of Mice and Otegr Uncommon THINGS IN FOOD.-A group of recent decisions presents a somewhat farcical conformity with Montesquieu's thesis that "law" may vary with time and geography. It strikingly illustrates, also, the importance of the particular theory of liability upon which a suit is predicated. The unusual similarity in detail of the operative facts of these cases lends peculiar emphasis to the difference in the judgments rendered.

The plaintiff in Merrill v. Hodson (July, I9I4), 88 Conn. 314, had been poisoned by the unwholesomeness of some creamed-sweetbreads, which had been prepared by defendant's servants and served to plaintiff in his restaurant. The suit, to recover for damage suffered, was based "in both pleading and proof" on the theory of an implied warranty that food so served was fit to be eaten. In other cases it had been held, and has since been held, that the serving of food in a restaurant was a "sale" within the meaning of statutes prohibiting sales of game, liquor, adulterated milk, etc. State v. Lotti, 72 Vt. I15; Com. v. Warren, I6o Mass. 533; People v. Clair, 221 N. Y. I08; Com. v. Phoenix Co., $157 \mathrm{Ky}$. I80; Com. v. Miller, I3I Pa. II8. This case, however, the court said, was the first case of its particular kind to come before a supreme appellate tribunal. The court held that neither by the common law nor in the sense of the Uniform Sales Act was the transaction between a restaurant keeper and a patron a "sale," and that as there was no "sale" there could be no implied warranty. The plaintiff was therefore denied recovery. (While the court seems to have been correct in its statement that no similar case had come before a supreme tribunal, such 
cases had been before the intermediate courts of New York, in Leahy $\mathrm{v}$. Essex Co. (July, 1914), I48 N. Y. S. 1063, and Race v. Krum (1913), I46 N. Y. S. r97, affirmed, 222 N. Y. 410 , and in both cases the transaction had been held to be a sale.) A conclusion that such transactions are not sales was reached by the federal court in Valeri v. Pullman Co. (Dec., 1914), 218 Fed. 519.

At this time there was apparent in other decisions a strong tendency to hold persons who prepare food for human consumption to be under a duty of so high a degree of care as to make them almost insurers of the fitness for use of such food. The unfitness of the food practically branded, per se, the one who had prepared it as negligent. In Parks v. Yost Pie Co. (Nov., 1914), $93 \mathrm{Kan}$. 334, decided the same year as the Connecticut case, it appeared that the plaintiff's husband had died as the result of poison in a pie prepared by defendant company and sold by it to a retailer, who, in turn, sold it to plaintiff's husband. There was no privity of contract between plaintiff, or her husband, and the defendant on which any pretense of contract could be based. The action was in tort, on the theory of negligence. No direct proof of negligence appears in the report of the case, nor is it even suggested. Nevertheless, a verdict for plaintiff was sustained on the ground that a manufacturer of food for human consumption is held to so high a degree of care, because of the serious consequences which might follow negligence, that "Practically he must know it is fit or take the consequences." (Citing Tomlinson v. Armour \& Co., 75 N. J. L. 748). The Washington courts, in the preceding year, had reached the same conclusion, and held a defendant liable, in an action based on tort, without any proof of negligence other than the fact that the food was unwholesome. Mazetti v. Armour \& Co. (I9I3), 75 Wash. 622. In Jackson v. Cocoa Cola Co. (Mo., April, I914), 64 So. 79I, it appeared that plaintiff had found, too late, a swollen and mephitic mouse in Cocoa Cola bottled by the defendant and sold to a retailer, who resold to plaintiff. There was no evidence that the defendant had been negligent in bottling the mouse. "How it happened is not told." The court held the bottler to be "under a legal duty to see to it that in the process of bottling no foreign substance shall be mixed with the beverage, which, if taken into the human stomach will be injurious," and that this duty is owing, "to the general public for whom his drinks are intended as well as to the retailer to whom he sells." In a number of actions by patrons directly against the restaurant keeper whose unwholesome food had injured them, it had been held, "that every one ought to know the qualities, good or bad, of the things which he fabricates in the exercise of the art, craft or business of which he makes public profession.*** $\mathrm{He}$ is therefore at fault if these articles prove to be vitiated or deleterious." Doyle v. Fucrst, I29 La. 838; Pantaze v. West. 7 Ala. App. 599. This liability was denied only by an occasional case such as Valeri $\nabla$. Pullman Co., 2IS Fed. 519, requiring only the carefulness of a reasonably prudent man, and Liggett \& Miyers Tobacco Co. v. Cannon (IgI5), I32 Tenn. 4I9, I4 Mice. L. Rev. I64. The latter denied a manufacturer's liability for the presence of a bug in a plug of tobacco. This decision, however, was differentiated on the ground that tobacco is not food, and might have been on the 
ground that the damage resulting from a bug in chewing tobacco would be nominal at most.

In view of this definite authority on either theory, the attorney might be pardoned who chose thereafter to sue a restaurant keeper on the theory of implied negligence rather than that of sale and implied warranty. In 1916 , in Jacobs v. Childs Co., 166 N. Y. S. 798, "counsel for the plaintiff at first proceeded upon the theory of the defendant's implied warranty of the fitness of the food for consumption; but subsequently moved to change the cause of action to one in tort predicated upon the negligence of the defendant ***" The plaintiff had been injured through biting on a nail hidden in a cake manufactured by the defendant and served in defendant's restaurant. The court denied liability of the defendant, on the ground that no negligence had been directly proved and that it could not be inferred from the facts of this case. It pointed out a distinction between a cake containing deleterious and unwholsome ingredients and a cake containing a foreign substance but otherwise fit for human consumption. The latter is not, the court said, like the former, a case of res ipsa loquitur, although "if the nail had been necessarily used in the making of the cake or were an integral part thereof, a different situation would be presented." (Citing Hasbrouck v. Arnour \& Co., I39 Wis. 357; distinguishing Watson v. Augusta Co., I24 Ga., I2I and Garvey v. Namm, I2I N. Y. S. 442). A remarkably similar case was decided in the same way this year. Ash v. Childs Co. (Mass., Sept., 1918), I20 N. E. 396 . The plaintiff was injured through biting on a tack in a piece of blueberry pie manufactured by defendant and supplied to plaintiff as a patron of its restaurant. The action was in tort, based on defendant's negligence. No direct proof was presented and the court refused to apply the doctrine of res ipsa loquitur. (Jacobs v. Childs Co., supra, was not cited.) The question of negligence was left to the jury in Grcenwood Café v. Lovinggood (I916), I97 Ala. 34 In Crigger v. Cocoa Cola Co. (1915), 132 Tenn. 545, the action was based on averment of negligence, for damages resulting from plaintiff's having swallowed a long defunct mouse interred in Cocoa Cola, bottled by the defendant, and sold to a retailer, who sold to plaintiff. The court held that there was no implied warranty which would "run with the article" because the article was not "inherently dangerous," and that evidence of actual negligence was essential to recovery. Accord, Gearing v. Berkson, 223 Mass. 257; in this case, however, the defendant while a dealer, had not prepared the article in any way relative to the defect.

While the cases contemporaneous with Mferrill v. Hodson were being thus disregarded and distinguished, counsel who, despite that case, stuck to the idea of sale and warranty were winning. In Friend r. Childs Co. (Mass., Sept., IgI\$), i20 N. E. 407 the plaintiff sucd for injury suffered through biting on a stone in a dish of baked beans prepared by defendant, and served in its restaurant. Here, again, there was no direct proof of negligence. And certainly the presence of a stone in the beans would no more justify application of the doctrine of res ipsa loquitur than would the presence of a nail in the cake or a tack in the pie. But in this case the suit was based on the theory of "breach of an implied warranty of fitness to eat, in a 
contract for food-." The court strongly leaned toward the position that the transaction was a "sale," but held that, in any event, it was a contract to furnish food, which contract impliedly contained a term that the food should be fit for use. In a somewhat startling case of the same year, Barrington v. Hotel Astor (July, I9I8), I7I N. Y. S. 840, such a transaction was held unqualifiedly to be a sale. The plaintiff had ordered kidney saute in the defendant's restaurant and was made violently sick by the discovery therein of a mouse, chopped in two. There was no direct proof of negligence, indeed the defense was that plaintiff had "planted" his own mouse in the dish with a view to such a suit. The court held that "under modern conditions the food is sold and the hotel keeper impliedly warrants that it is wholesome to eat". Thus New York and Massachusetts seem fairly well settled on both theories, but otherwise the whole result is Biblical, authority for both sides upon either theory. J. B. W. 